\title{
KEBIJAKAN STRATEGIS DAN LOCAL WISDOM TATA KELOLA HUTAN DAN LAHAN DI PROVINSI RIAU
}

\author{
Zamhasari \\ Program Studi llmu Pemerintahan \\ Universitas Abdurrab, Pekanbaru - Riau, Indonesia \\ E-mail: zamhasari@univrab.ac.id \\ T. Fahrul Gafar \\ Program Studi Ilmu Pemerintahan \\ Universitas Abdurrab, Pekanbaru - Riau, Indonesia \\ E-mail: gaffar@univrab.ac.id
}

\begin{abstract}
This study seeks to analyze strategic policies and local wisdom that exist in local communities in governancing and managing forests in Riau Province. This research uses qualitative method with case study research type. This study concludes that forest and land governances in Riau is still poor. The government has also not seriously implemented the strategy that has been made to resolve the case of forest and land fires. Increasing the budget in preventive efforts must be accompanied by efforts to improve budget governance that is more transparent and accountable. The role of the local government in overcoming unresolved land degradation conditions must be a priority that should not be ignored.
\end{abstract}

Keywords: Anticipation, Policy, Forest Fire, Land

\section{PENDAHULUAN}

Reformasi Indonesia yang telah berlangsung sejak 1998 dan pemberian otonomi daerah kepada provinsi, kabupaten dan kota di Indonesia, termasuk di Provinsi Riau ternyata belum membawa hasil yang maksimal dalam menata dan mengelola hutan yang ada di wilayah Provinsi Riau. Sejak reformasi Indonesia, dan daerah Provinsi Riau turut menikmati status otonomi daerah tersebut ditandai dengan euphoria pemilihan kepada daerah Provinsi Riau dan terbukti pula bahwa pada Pemilihan Gubernur Provinsi Riau (Pilgubri) yang dihelat dalam suasana reformasi Indonesia tersebut, Gubernur Riau terpilih untuk periode 1998-2013 adalah putra asli daerah Riau sendiri. Ini adalah Pemilihan Kepala Daerah terakhir yang menggunakan UU Nomor 5 Tahun 1974 Tentang Pokok-pokok Pemerintahan di Daerah. Pilgubri untuk periode 2003-2008, 2008-2013, 2013- 2018 serta 2018-2023 juga menempatkan putra daerah Provinsi Riau sebagai Gubernurnya.

Melalui otonomi daerah dan Gubernur Riau yang juga merupakan putra daerah Provinsi Riau, masyarakat Riau berharap banyak hal untuk mencapai taraf 
kesejahteraan hidup, terutama dalam bidang pertanian. Namun, cita-cita masyarakat untuk hidup sejahtera melalui pertanian tersebut belum dapat diaktualisasikan secara maksimal. Sebaliknya, hal memilukan yang terus terjadi hingga hampir $1 / 8$ abad reformasi Indonesia adalah terus berlangsungnya kebakaran hutan dan lahan yang tiada henti (Panjaitan, 2015).

Berdasarkan pantauan satelit Modis (Terra dan Aqua) periode September 2000 sampai Juli 2008 di wilayah Provinsi Riau dijumpai 57.972 titik api yang terdistribusi ke dalam 12 kabupaten/ kota. Kejadian ini hampir setiap tahun berulang ditempat yang sama terutama pada kawasan bergambut. Titik api tersebar pada dua tipe tanah, yaitu tanah mineral dan tanah gambut. Dari 57.027 titik api yang ditemukan, 17.259 titik api ditemukan pada tanah mineral atau 30,24\% sedangkan 39813 atau $69,76 \%$ lainnya dijumpai pada tanah bergambut dengan kedalaman bervariasi. Distribusi titik api paling banyak terdapat pada gambut dengan kedalaman 4 meter lebih dengan jumlah titik api ditemukan sebanyak 13.909 atau $24,37 \%$. Sedangkan paling kecil berada pada kawasan gambut dangkal dengan kedalaman kurang dari 0,5 meter dengan jumlah titik api sebanyak 239 titik atau $0,4 \%$.

Salah satu tantangan besar yang perlu dijawab dalam upaya mewujudkan pembangunan kehutanan yang berkelanjutan terletak pada pelibatan semua pemangku kepentingan. Prosedur dan birokrasi tata kelola kehutanan yang dilandaskan pada prinsip transparansi, partisipasi, akuntabilitas dan koordinasi akan memberikan ruang yang lebih besar untuk mewujudkan upaya pembenahan sektor kehutanan di Indonesia dan menurunkan tingkat deforestasi maupun degradasi. Tantangan terkait dengan lemahnya penataan ruang, ketidakpastian tenurial, dan unit manajemen yang lemah mengakibatkan pengelolaan hutan menjadi sangat eksploitatif, menyumbangkan deforestasi di Indonesia sekitar 1,1 juta/ha (Dirjen Planologi Kehutanan untuk periode 2006-2009). Reformasi Indonesia yang sudah dicapai melalui pengorbanan raga dan jiwa anak bangsa ini sejatinya menjadikan rakyat Indonesia mencapai taraf hidup yang lebih baik dari orde atau masa sebelum reformasi. Begitu pula dengan pelimpahan sebagian wewenang pemerintah pusat kepada pemerintah daerah melalui otonomi daerah idealnya menjadikan daerah tersebut lebih baik dari sebelumnya. 
Berdasarkan pada uraian yang sudah dipaparkan pada latar belakang penelitian ini, dapatlah dirumuskan beberapa pokok permasalahan. Pertama, reformasi Indonesia 1998 memiliki andil dan peran yang cukup besar dalam mempengaruhi dinamika perpolitikan di Indonesia. Bila pada masa sebelum reformasi, animo dan antusias masyarakat untuk terlibat secara aktif dalam organisasi-organisasi sosial kemasyarakatan masih sangat rendah, namun fenomena tersebut berubah total pasca reformasi. Kedua, otonomi daerah yang dilimpahkan oleh pemerintah pusat kepada pemerintah daerah membuka peluang yang cukup besar kepada putra-putri terbaik dan potensial di daerah terkait untuk tampil sebagai pemimpin atau kepala daerah. Hanya saja, jabatan dan amanah yang didapat melalui prosesi pemilihan itu sering kali dinodai dengan aksi memperkaya diri, kelompok atau golongan sekaligus membangun dinasti kepemimpinan di daerah itu. Terbukti, sejak reformasi digulirkan dan otonomi daerah dilimpahkan, belum ada kepala daerah Provinsi Riau yang notabene adalah putra-putra terbaik Riau yang lepas dari jeratan hukum karena jabatan dan status yang melekat padanya.

\section{STUDI LITERATUR}

\section{Tata Kelola Hutan}

Penataan dan pengelolaan hutan (Herman, 2008) haruslah dilakukan secara arif dan berkesinambungan, hal ini mengingat hutan merupakan paru-paru dunia. Dengan demikian keselamatan dan kelestarian hutan adalah modal awal untuk menjaga keselamatan dan kelestarian dunia ini. Kerusakan hutan akan turut berkontribusi terhadap kerusakan dunia dan alam pula. Keterbatasan informasi tentang tata-kelola hutan dari instansi terkait menjadi kendala bagi masyarakat untuk turut andil dalam mengawasi dan mengontrol kinerja pemerintah Provinsi Riau.

\section{Local Wisdom}

Istilah kearifan lokal itu terjemahan dari local genius yang diperkenalkan pertama kali oleh Quaritch Wales (1948-1949) dengan arti kemampuan kebudayaan setempat dalam menghadapi pengaruh kebudayaan asing pada waktu kedua kebudayaan tersebut berhubungan (Rosidi, 2010:1). Pendapat lain dari Ahimsa-Putra (t.t.:5) mendefinisikan kearifan lokal adalah perangkat 
pengetahuan dan praktek-praktek pada suatu komunitas - baik yang berasal dari generasi-generasi sebelumnya maupun dari pengalamanya berhubungan dengan lingkungan dan masyarakat lainnya - untuk menyelesaikan secara baik dan benar persoalan dan/atau kesulitan yang dihadapi, yang memiliki kekuatan seperti hukum maupun tidak.

Menurut Ridwan (2010:2) kearifan lokal atau sering disebut local wisdom dapat dipahami sebagai usaha manusia dengan menggunakan akal budinya (kognisi) untuk bertindak dan bersikap terhadap sesuatu, objek, atau peristiwa yang terjadi dalam ruang tertentu. Selanjutnya dikatakan bahwa wisdom dipahami sebagai kemampuan seseorang dalam menggunakan akal pikirannya dalam bertindak atau bersikap sebagai hasil penilaian terhadap sesuatu, objek, atau peristiwa yang terjadi. Sebagai sebuah istilah wisdom sering diartikan sebagai kearifan/ kebijaksanaanll. Lokal secara spesifik menunjuk pada ruang interaksi terbatas dengan sistem nilai yang terbatas pula.

\section{METODE PENELITIAN}

Dalam melakukan penelitian ini, peneliti menggunakan pendekatan kualitatif dengan tipe penelitian studi kasus. Hal ini dilakukan agar tetap sejalan dengan tujuan penelitian, yaitu untuk menganalisa local wisdom dalam penataan dan pengelolaan hutan di Provinsi Riau, khususnya pasca reformasi Indonesia 1998 tersebut. Untuk mempertajam analisa dalam penelitian ini, peneliti memiliki beberapa pendekatan yaitu pendekatan emosional, pendekatan ruang dan waktu dan pendekatan teori.

Data penelitian ini terdiri dari data primer dan data sekunder. Sebagian data primer ini diperoleh melalui hasil dokumentasi yang berkaitan dengan tata-kelola hutan, khususnya di Provinsi Riau. Data sekunder diperoleh melalui surat kabar, majalah, internet dan sebagainya yang tentunya dengan mempertimbangkan akurasi sumber informasi.

Dalam menganalisis dan penyajian data, peneliti merasa condong kepada tahapan-tahapan yang dikemukakan oleh Creswell (2007), tahapan-tahapan tersebut meliputi: data managing, reading and memoing, describing, classifying, interpreting, serta representing and visualizing. 


\section{PEMBAHASAN}

\section{Alih Fungsi Lahan}

Konversi atau alih status fungsi hutan serta perubahan dalam reproduksi sumber daya hutan disebabkan oleh beberapa faktor. Sejak paruh kedua abad ke20, penebangan liar dan hutan tanaman industri $(\mathrm{HTI})$ telah menjadi faktor utama penyebab perubahan tutupan hutan di negara-negara seperti Indonesia, Malaysia, dan Filipina. Produksi dan pembukaaan lahan perkebunan terutama yang didominasi oleh kelapa sawit di negara-negara tersebut telah menyebabkan pembukaan dan konversi hutan yang cukup besar.

Tak kalah pentingnya juga, faktor lain dari penyebab perubahan kondisi hutan dan cukup dramatis adalah kebakaran, yang pada akhirnya terkait erat dengan penebangan, pembukaan lahan, dan produksi tanaman perkebunan modern (Dennis et al., 2001). Semua faktor yang menyebabkan terjadinya perubahan pada kondisi hutan ini merupakan faktor yang memiliki implikasi jangka panjang yang kompleks dan heterogen, namun semuanya memiliki kesamaan yang mendasarinya, yaitu kepentingan ekonomi. Inilah kepentingan yang diklaim oleh berbagai kelompok dalam masyarakat.

Pada tingkat analisis yang paling intim, ekologi politik berupaya menganalisis dampak perubahan lingkungan, ekonomi dan sosial pada masyarakat lokal. Dengan kemajuan pasar global modern, interkoneksi antara sejarah lokal yang berbeda menjadi lebih sulit untuk diurai. Efek pada hutan dan penghuninya tidak merata dari satu tempat ke tempat lain. Kemiskinan, sebagaimana disebutkan sebelumnya, tidak dengan sendirinya menjadi penyebab kerusakan hutan (Dove, 1993).

Gagasan tentang hutan, dan lebih luas lagi tentang lingkungan, sering menjadi sasaran manipulasi diskursif. Di Malaysia, misalnya, luas sebenarnya dari lahan yang tersisa di bawah tutupan hutan sangat diperdebatkan, lembaga pemerintah menggunakan berbagai kriteria tergantung pada statistik apa yang digunakan untuk menentukan apa yang disebut sebagai hutan (Sahabat Alam Malaysia 2001).

Pengembangan hutan rawa gambut di Indonesia merupakan upaya terakhir oleh rezim Suharto untuk meyakinkan penduduk bahwa pemerintah masih peduli 
untuk menciptakan pembangunan. Kekuatan analisis ekologi politik ini ada pada terbukanya peluang kritik, yang merupakan langkah pertama dalam menemukan solusi yang tepat. Berkenaan dengan solusi, paradigma yang dipaksakan secara global atau lokal tidak tepat. Ketika efek degradasi berlanjut dengan cepat, banyak tindakan perlu dirancang, masing-masing fleksibel terhadap masalah yang dialaminya dan peka terhadap sejarah hutan lokal yang menjadi dampaknya. Mengingat keterkaitan di antara komunitas, agen, dan negara di seluruh dunia, solusi tidak akan langsung datang saat itu juga.

\section{Kebijakan Antisipasi Kebakaran Hutan dan Lahan}

Kebakaran hutan dan lahan di Indonesia yang diakibatkan oleh ekspansi lahan pertanian melonjak terutama pada setiap musim kemarau, menyebabkan kabut dan krisis kesehatan masyarakat, termasuk lebih dari 100,000 kematian dini di wilayah Asia Tenggara. Walaupun kebakaran kembali terjadi tahun ini, kebakaran tahun ini tidak seburuk kebakaran tahun-tahun sebelumnya. Sampai dengan kuartal ketiga 2016, peringatan kebakaran di Indonesia hanya seperempat dibandingkan dengan peringatan kebakaran pada 2015 pada periode waktu yang sama.

\section{Kebijakan Srategis Pemerintah Provinsi Riau Mengatasi Karhutla}

Dalam mengantisipasi Karhutlla di Riau, Pemerintah Provinsi Riau sudah membuat kebijakan strategis, yaitu: pemetaan daerah rawan bencana, reinventarisasi izin usaha bidang perkebunan dan kehutanan yang beroperasi di Riau, patroli bersama antara pemerintah provinsi dengan perusahaan yang dimonitor oleh satgas karhutla, menyediakan alat pertanian yang menunjang pencegahan karhutla seperti eskavator dan pompa, memberdayakan masyarakat sekitar hutan, mensosialisasikan bahaya karhutla, komitmen bersama antara Pemprov dengan Pemko/Pemkab untuk mencegah dan menanggulangi karhutla, bekerjasama dengan Polda Riau dalam bidang sistem informasi deteksi dini untuk mengetahui titik api di lapangan, pembuatan embung dan sekat kanal di lahan gambut, penetapan tim terpadu penertiban kebun sawit ilegal, penerbitan Perda Riau No. 1 Tahun 2019 tentang Pedoman Teknis Penanggulangan Kebakaran Hutan dan Lahan. 


\section{Local Wisdom Dalam Menata Dan Mengelola Hutan Di Riau Pasca Reformasi Indonesia}

Alam bagi masyarakat Melayu Riau adalah suatu hal sentral bagi kehidupan. Di sanalah tempat mencari penghidupan dan bisa bertahan hidup. Namun hormat mereka kepada alam bukan hanya karena mereka bisa memanfaatkan saja, melainkan juga kewajiban untuk terus menjaga. Kewajiban tersebut tercermin dari pepatah (atau petatah petitih) generasi tua yang menyatakan jika alam binasa, adatpun juga akan binasa.

Keseluruhan wujud nilai tanggung jawab tersebut diistilahkan sebagai sebuah kearifan lokal (local wisdom). Kearifan lokal adalah prinsip-prinsip dan cara tertentu yang dianut, dipahami, dan diaplikasikan oleh masyarakat lokal dalam berinteraksi dan berinterelasi dengan lingkungannya dan diformulasikan dalam bentuk sistem nilai dan norma adat. Bentuk-bentuk dari kearifan lokal antara lain adalah petuah amanah, etika-etika atau perilaku yang dianjurkan, dan nilai serta norma. Yang lebih menarik, kewajiban menjaga alam juga dipengaruhi oleh nilai keislaman bahwa manusia adalah khilafah pemimpin yang harus bertanggung jawab di Bumi, akibat adanya asimilasi nilai Islam dalam kehidupan masyarakat Melayu.

Dampak dari realitas ini adalah hilangnya sumber penghidupan masyarakat adat, punahnya nilai luhur adat pada jangka panjang, dan pada akhirnya merusak alam peninggalan peradaban ribuan tahun lalu. Pada kenyataannya, iklim dunia yang makin hangat, ekstrim, dan susah diprediksi sudah menjadi indikasi bahwa alam sudah mulai protes dan semakin dengan ajalnya jika manusia terus bersikap tidak peduli. Oleh karena itu, butuh jembatan atau kerjasama antara masyarakat adat dengan pemerintah setempat serta antara semua komponen masyarakat Riau agar upaya konservasi alam menjadi sebuah upaya bersama (kolektif) yang butuh kepastian dan tindak nyata.

\section{KESIMPULAN}

Kebakaran hutan dan lahan seolah menjadi masalah musiman tiap tahun di beberapa daerah di Indonesia, termasuk Riau. Hal tersebut terus terjadi karena adanya tata kelola yang buruk dalam pencegahan kebakaran hutan dan lahan di Indonesia. Pemerintah belum serius terhadap upaya penyelesaian kasus ini, 
hal tersebut ditunjukkan dengan minimnya anggaran untuk belanja kehutanan khususnya untuk upaya preventif. Peningkatan anggaran dalam upaya preventif, karena hal tersebut dinilai lebih baik daripada mengeluarkan banyak anggaran hanya untuk langkah reaktif (pemadaman kebakaran), tentunya dengan perbaikan tata kelola anggaran pencegahan yang lebih transparan dan akuntabel. Perencanaan dan alokasi anggaran untuk mencegah kebakaran hutan perlu di prioritaskan. Peran Pemda untuk mengatasi kondisi degradasi lahan yang belum membaik harus menjadi prioritas yang tidak boleh diabaikan.

Pemerintah perlu meninjau ulang izin konsesi, khususnya lahan konsesi yang terbakar. Pemerintah Pusat juga harus segera melaksanakan putusan Mahkamah Agung terkait karhutla. Peninjauan Kembali (PK) yang dilakukan pemerintah saat ini tidak relevan serta melukai hati rakyat. Mengeluarkan moratorium permanen bagi hutan primer dan ekosistem gambut dengan mempertimbangkan wilayah yang bisa dikelola oleh masyarakat dan endesak pemerintah untuk membuat peraturan yang menjamin penghormatan dan perlindungan kearifan lokal masyarakat untuk mengolah lahan pertanian turun temurun. Dalam upaya antisipasi Karhutla, negara harus berpihak pada masyarakat termasuk kearifan lokalnya yang juga dilindungi Undang-undang.

\section{REFERENSI}

Ahimsa-Putra, Hedi Shri. (tt). Bahasa, Sastra dan Kearifan Lokal di Indonesia. Yogyakarta: Fakultas IImu Budaya, UGM.

Dennis, R., A. Hoffmann, G. Applegate, G. von Gemmingen, and K. Kartawinata. 2001. Large-Scale Fire: Creator and Destroyer of Secondary Forests in Western Indonesia. Journal of Tropical Forest Science 13(4):786-799.

Dove. 1993. A Revisionist View of Tropical Deforestation and Development. Environmental Conservation 20:17-24.

Hidayat, Herman, 2008. Politik Lingkungan: Pengelolaan Hutan Masa Orde Baru dan Reformasi. Jakarta: Yayasan Obor Indonesia.

Ridwan, Nurma Ali, 2010. Landasan Keilmuan Kearifan Lokal. http:// www.nusantara-online.com.

Rosidi, Ajip, 2010. Kearifan Lokal dan Pembangunan Bangsa. International Conference Proceedings on Traditional Culture and Rancage Award 2010, hal. 28-35. 